\title{
Pengaruh Model Pembelajaran Problem Based Learning dan Ekspositori terhadap Kemampuan Berpikir Kritis dalam Pembelajaran IPS tentang Keragaman Budaya pada Siswa Kelas IV SD Negeri se-Kecamatan Kutowinangun
}

\author{
Sugiharti, Joharman, Suhartono \\ PGSD FKIP Sebelas Maret University \\ hartiharti113@gmail.com
}

\section{Article History}

accepted 01/10/2020

\begin{abstract}
The Influence Of Problem Based Learning Model And Expository Model On Critical Thinking Skills In Social Science About Cultural Diversity To Fourth Grade Students Of Elementary Schools In Kutowinangun Sub-District. Problem based learning is approach to learning that improves students thinking skills. The study aimed to prove that students learning through Problem Based Learning (PBL) model had better critical thinking skills than through Expository model in social science about cultural diversity to fourth grade students of elementary schools in Kutowinangun Sub-District. It was a quasi-experimental quantitative research design. The data analysis used free sample $t-2$ test with the help of PASW application. The result showed that students learning through Problem Based Learning (PBL) model had better critical thinking skills than through Expository model. It was proven by the Sig. value in hypothesis test which was 0,000 . It concludes that students learning through Problem Based Learning (PBL) model had better critical thinking skills than through Expository model in social science about cultural diversity to fourth grade students of elementary schools in Kutowinangun Sub-District.
\end{abstract}

Keywords: PBL, expository, critical thinking skills

\begin{abstract}
Abstrak
Pengaruh Model Pembelajaran Problem Based Learning dan Ekspositori Terhadap Kemampuan Berpikir Kritis dalam Pembelajaran IPS Tentang Keragaman Budaya Pada Siswa Kelas IV SD Negeri se-Kecamatan Kutowinangun. ProblemmBased Learning adalah model pembelajaran yang dapat meningkatkan kemampuan berpikir siswa. Penelitian ini bertujuan untuk membuktikan bahwa kemampuan berpikir kritis siswa yang belajar dengan model Problem Based Learning lebih baik dari siswa yang belajar dengan model ekspositori dalam pembelajaran IPS tentang keragaman budaya kelas IV SDN se-Kecamatan Kutowinangun. Penelitian ini merupakan penelitian kuantitatif desain quasi eksperimen. Analisis data menggunakan uji t-2 sampel bebas. Hasil penelitian menunjukkan bahwa kemampuan berpikir kritis siswa yang belajar dengan model Problem Based Learning lebih baik dari siswa yang belajar dengan model ekspositori yang ditunjukkan pada uji hipotesis bahwa nilai Sig. sebesar 0.000 . Berdasarkan penelitian dapat disimpulkan bahwa kemampuan berpikir kritis siswa yang belajar dengan model Problem Based Learning lebih baik dari siswa yang belajar dengan model ekspositori dalam pembelajaran IPS tentang keragaman budaya kelas IV SDN se-Kecamatan Kutowinangun.
\end{abstract}

Kata kunci: PBL, ekspositori, kemampuan berpikir kritis 


\section{PENDAHULUAN}

IImu Pengetahuan Sosial (IPS) merupakan salah satu mata pelajaran yang dipelajari dalam kurikulum 2013. Tolok ukur keberhasilan dari proses pembelajaran IPS yaitu apabila siswa dapat menguasai konsep dan mampu memecahkan masalah sesuai dengan konsep yang ada. Untuk memecahkan permasalahan diperlukan salah satu kemampuan yang ada dalam HOTS (High Order Thinking Skills) yaitu kemampuan untuk berpikir kritis. Menurut Dewey (Fisher, 2017) berpikir kritis sebagai proses memikirkan sesuatu hal secara mendalam, mengajukan berbagai pertanyaan, dan menemukan informasi yang relevan. Scriven \& Paul (Anggriani, Karyadi, dan Ruyani, 2018) berpendapat bahwa berpikir kritis adalah proses berpikir secara aktif dan terampil untuk membangun konsep, mencari, menerapkan, mensintesis, menganalisis, serta mengevaluasi informasi yang diperoleh melalui pengamatan, pengalaman, penalaran, atau komunikasi untuk memandu apa yang harus dilakukan.

Kenyataan di lapangan, siswa belajar IPS menggunakan teknik menghafal, sehingga siswa kurang meningkatkan kemampuannya untuk berpikir secara kritis. Hal di atas diperkuat dengan hasil wawancara dengan salah satu guru kelas IV SD Negeri di Kecamatan Kutowinangun bahwa masih cukup banyak siswa yang belum memahami konsep IPS dengan baik. Selain itu tingkat berpikir kritis siswa dalam pembelajaran IPS juga cukup rendah, yaitu hanya berkisar $10 \%-15 \%$. Pembelajaran juga kurang bermakna karena belum memberikan kesempatan kepada siswa untuk menemukan sendiri dan melakukan pemecahan masalah.

Pembelajaran yang seharusnya dilaksanakan yaitu pembelajaran yang merangsang siswa untuk meningkatkan kemampuan berpikir, keterampilan dan pembentukan sikap. Upaya yang efektif untuk mewujudkan pembelajaran tersebut, yakni dengan menerapkan model pembelajaran yang berpusat pada siswa serta mampu mengembangkan kemampuan siswa. Salah satu model pembelajaran yang inovatif dan berpusat pada siswa adalah model pembelajaran ProblemmBased Learning (PBL). Problem Based Learning (PBL) merupakan model pembelajaran yang fokus dengan pemecahan permasalahan yang ada pada kehidupan siswa. Wulandari, Astuti dan Widodo (2018) menyatakan bahwa model pembelajaran Problem Based Learning (PBL) adalah model pembelajaran yang mengharuskan siswa lebih aktif untuk memahami konsep melalui penyajian masalah yang bertujuan melatih siswa untuk menyelesaikan permasalahan. Menurut Herzon, Budijanto, Utomo (2018) langkah-langkah pembelajaran Problem Based Learning (PBL) yaitu a) memberikan orientasi permasalahan pada siswa; b) mengorganisasikan siswa untuk melakukan penelitian; c) membantu penyelidikan mandiri dan kelompok; d) mengembangkan serta menyajikan hasil atau artefak; dan e) menganalisis serta mengevaluasi proses pemecahan masalah.

Dalam pembelajaran Problem Based Learning (PBL) terdapat kegiatan kerja kelompok, diskusi, umpan balik antara guru dan siswa. Model pembelajaran Problem Based Learning dapat berpengaruh terhadap keterampilan berpikir kritis. Hal ini sesuai dengan pendapat Smith (Amir, 2010) yang menyatakan bahwa model Problem Based Learning dapat meningkatkan kecakapan pemecahan masalah, lebih mudah mengingat, meningkatkan pemahaman, dan pengetahuan yang relevan dengan dunia praktik serta mendorong siswa untuk penuh pemikiran.

Penelitian tentang pengaruh model pembelajaran Problem Based Learning terhadap keterampilan berpikir kritis yang dilakukan oleh Amin (2017) yang berjudul "Pengaruh Model Pembelajaran Problem Based Learning terhadap Kemampuan Berpikir Kritis dan Hasil Belajar Geografi" menyatakan bahwa bahwa kemampuan berpikir kritis siswa kelas eksperimen lebih tinggi daripada kelas kontrol. Perbedaan penelitian ini dengan penelitian sebelumnya yaitu penelitian ini dilaksanakan pada tingkat sekolah dasar, yaitu mengukur kemampuan berpikir kritis dalam mata pelajaran IPS pada anak usia sekolah dasar. 
Model pembelajaran yang saat ini masih banyak digunakan adalah model pembelajaran ekspositori atau yang disebut dengan pembelajaran konvensional. Pembelajaran dengan model ekspositori lebih menekankan pada penguasaan materi oleh siswa. Menurut Jacobson, et al (Harjono, dkk. 2018) model pembelajaran ekspositori merupakan model pembelajaran yang berpusat pada guru dan guru adalah sumber informasi utama yang memberikan informasi tentang konsep, menyajikan keterampilan, memberikan contoh serta penyelesaiaannya dan guru memberikan kesempatan untuk bertanya. Pada model ekspositori peran guru lebih dominan, karena materi lebih banyak disampaikan oleh guru, sehingga kemungkinan besar siswa yang memiliki kemampuan rendah lebih mudah memahami pembelajaran dengan menerapkan model ini. Menurut Marisa (2019) model pembelajaran ekspositori memiliki empat langkah pembelajaran yaitu a) persiapan, yaitu tahap mempersiapkan siswa untuk menerima pelajaran; b) penyajian, yaitu tahap penyampaian materi oleh guru; c) korelasi, yaitu tahap mengaitkan materi pembelajaran kehidupan siswa; dan d) menyimpulkan, yaitu tahap memahami inti dari pelajaran.

Berdasarkan latar belakang yang telah diuraikan di atas, maka rumusan masalah dalam penelitian apakah terdapat pengaruh model pembelajaran Problem Based Learning (PBL) dan model Ekspositori terhadap kemampuan berpikir kritis dalam pembelajaran IPS tentang keragaman budaya pada siswa kelas IV SD Negeri se-Kecamatan Kutowinangun.Tujuan penelitian ini yaitu untuk membuktikan bahwa terdapat pengaruh model pembelajaran Problem Based Learning (PBL) dan model Ekspositori terhadap kemampuan berpikir kritis dalam pembelajaran IPS tentang keragaman budaya pada siswa kelas IV SD Negeri se-Kecamatan Kutowinangun.

\section{METODE}

Penelitian ini termasuk dalam penelitian kuantitatif desain quasi experiment. Populasi penelitian ini yaitu siswa kelas IV SD Negeri se-Kecamatan Kutowinangun. Untuk teknik pengambilan sampel dalam penelitian ini menggunakan stratified cluster random sampling. Sampel dalam penelitian berjumlah delapan SD Negeri yang ada di Kecamatan Kutowinangun.

Dalam peneltian ini, kemampuan berpikir kritis menjadi variabel terikat dan model Problem Based Learning dan ekspositori menjadi variabel bebas. Teknik pengumpulan data yang digunakan adalah teknik tes. Tes yang digunakan untuk mengukur kemampuan berpikir kritis adalah tes uraian dengan jumlah 15 soal. Untuk mendapatkan validitas kontruksi, instrumen dikonsultasikan dengan dosen pembimbing. Untuk mendapatkan validitas isi, instrumen tes disesuaikan dengan indikator pembelajaran. Instrumen diujicobakan di lapangan untuk mendapatkan validitas eksternal. Tes kemampuanlberpikir kritis diujicobakanlkepada 68 siswa, kemudian dilakukan analisislvaliditas instrumen kemampuan berpikir kritis dengan menggunakan aplikasi PASW. Berdasarkan uji validitas, dapat diketahuilbahwa 15 soal yang diujicobakan tergolonglvalid. Hasil uji reliabilitaslinstrumen tes kemampuanlberpikir kritis menunjukkanlnilai Cronbach's Alpha sebesar 0,732, sehingga dapat disimpulkan bahwa tes kemampuan bepikir kritis reliabel denganlkategori tinggi

Teknik analisis data yang digunakan dalam penelitian kuantitatif yaitu menggunakan statistik parametris. Dalam penelitian ini, data yang diperoleh akan dianalisis dengan menggunakan t-2 sampel bebas. Sebelum dilaksanakan uji hipotesis, dilaksanakan uji normalitas, uji homogenitas dan uji kesetaraan. 


\section{HASIL DAN PEMBAHASAN}

Data kemampuan berpikir kritis dalam penelitian ini yaitu data kemampuan berpikir kritis siswa dalam mata pelajaran IPS kelas IV SD Negeri. Berikut deskripsi data kemampuan berpikir kritis.

Tabel 1 Deskripsi Data Variabel Kemampuan Berpikir Kritis

\begin{tabular}{lrrrr}
\hline & \multicolumn{2}{c}{ Pretest } & \multicolumn{2}{c}{ Posttest } \\
& PBL & Ekspositori & PBL & Ekspositori \\
\hline N Valid & 79 & 74 & 79 & 74 \\
$\quad$ Missing & 0 & 0 & 0 & 0 \\
Range & 43 & 30 & 41 & 30 \\
Minimum & 30 & 30 & 50 & 50 \\
Maximum & 73 & 60 & 91 & 80 \\
Sum & 3514 & 3101 & 5732 & 4452 \\
Mean & 44.48 & 41.91 & 72.56 & 60.16 \\
Std. & 8.423 & 7.062 & 10.284 & 5.781 \\
Deviation & & & & \\
Variance & 70.945 & 49.868 & 105.763 & 33.425 \\
Skewness & 1.000 & .650 & -.308 & .859 \\
Kurtosis & 1.298 & -.158 & -.992 & 1.196 \\
\hline
\end{tabular}

Berdasarkan tabel 4.1 dapat diketahui bahwa terdapat peningkatan nilai kemampuan berpikir kritis pada saat posttest, baik pada pembelajaran dengan model Problem Based Learning maupun ekspositori. Hasil uji prasyarat dalam penelitian ini, yaitu:

1. Uji Normalitas

Berikut ini output uji normalitas pada variabel kemampuan berpikir kritis.

Tabel 2 Output Uji Normalitas Data Kemampuan Berpikir Kritis

\begin{tabular}{llrr}
\hline \multicolumn{2}{c}{ Kelas } & \multicolumn{2}{c}{ Nilai Sig. } \\
& & .200 & .092 \\
\hline Kelompok Atas & PBL & .119 & .200 \\
& Ekspositori & .125 & .200 \\
Kelompok Tengah & PBL & .088 & .089 \\
& Ekspositori & .141 & .200 \\
Kelompok Bawah & PBL & .068 & .200 \\
\hline
\end{tabular}

Berdasarkan hasil uji normalitas yang telah dilaksanakan, dapat diketahui bahwa nilai Sig. pada masing-masing kelas bernilai lebih dari $\alpha$. Berdasarkan data tersebut, maka $\mathrm{H}_{0}$ diterima atau data berdistribusi normal.

2. Uji Homogenitas

Berikut Output uji homogenitas kemampuan berpikir kritis.

Tabel 3 Output Uji Homogenitas Kemampuan Berpikir Kritis

\begin{tabular}{rrrrr}
\hline Box's M & Approx & df1 & df2 & Sig. \\
\hline 2.322 & 2.307 & 1 & 68203.219 & .129 \\
\hline
\end{tabular}

Berdasarkan hasil uji homogenitas pada tabel 4.3 di atas, dapat diketahui bahwa nilai Sig. $0.129>0,05$, maka dapat disimpulkan bahwa data sampel berasal dari populasi yang bersifat homogen.

3. Uji Kesetaraan

Berikut output uji kesetaraan kemampuan berpikir kritis. 
Tabel 4 Output Uji Kesetaraan Kemampuan Berpikir Kritis

\begin{tabular}{llccrrr}
\hline & & & & & \multicolumn{2}{c}{$\begin{array}{c}\text { Sig. (2- } \\
\text { tailed) }\end{array}$} \\
\hline Data & Equal variances assumed & 1.240 & Sig. & \multicolumn{1}{c}{ T } & Df & tal \\
& $\begin{array}{l}\text { Equal variances not } \\
\text { assumed }\end{array}$ & & & 2.043 & 151 & .058 \\
& & & & & & \\
\hline
\end{tabular}

Berdasarkan hasil uji kesetaraan pada tabel 4.9 di atas, dapat diketahui bahwa nilai Sig.0.058 > 0.05 maka dapat disimpulkan bahwa kemampuan berpikir kritis siswa sebelum adanya perlakuan sama.

Untuk mengetahui apakah terdapat pengaruh model Problem Based Learning dan Ekspositori terhadap kemampuan berpikir kritis, perlu diadakan uji pada masing-masing variabel bebas.Berikut output uji t-2 sampel bebas pada model Problem Based Learning dan model Ekspositori.

Tabel 5 Output Uji t-2 Sampel Bebas model Problem Based Learning

\begin{tabular}{|c|c|c|c|c|c|c|}
\hline & & $\mathrm{F}$ & Sig. & $\mathrm{T}$ & Df & $\begin{array}{l}\text { Sig. (2- } \\
\text { tailed) }\end{array}$ \\
\hline \multirow[t]{2}{*}{ DATA } & Equal variances assumed & 7.939 & .005 & -18.772 & 156 & .000 \\
\hline & $\begin{array}{l}\text { Equal variances not } \\
\text { assumed }\end{array}$ & & & -18.772 & 150.170 & .000 \\
\hline
\end{tabular}

Tabel 6 Output Uji t-2 Sampel Bebas model Ekspositori

\begin{tabular}{|c|c|c|c|c|c|}
\hline & & $\mathrm{F}$ & Sig. & Df & $\begin{array}{l}\text { Sig. }(2- \\
\text { tailed) }\end{array}$ \\
\hline \multirow[t]{2}{*}{ DATA } & Equal variances assumed & 3.139 & $.079-17.208$ & 146 & .000 \\
\hline & $\begin{array}{l}\text { Equal variances not } \\
\text { assumed }\end{array}$ & & -17.208 & 140.524 & .000 \\
\hline
\end{tabular}

Berdasarkan hasil uji t-2 sampel bebas diperoleh nilai Sig. sebesar 0.000 dengan taraf signifikan $\alpha=0.05$, baik pada siswa yang belajar dengan model Problem Based Learning maupun siswa yang belajar dengan model ekspositori dengan membandingkan nilai pretest dan posttest. Hal ini menunjukkan bahwa terdapat perbedaan kemampuan berpikir kritis pada siswa sebelum adanya perlakuan dan sesudah perlakuan. Dengan demikian, dapat diketahui bahwa model Problem Based Learning dan model Ekspositori berpengaruh terhadap kemampuan berpikir kritis siswa dalam pembelajaran IPS tentang keragaman budaya pada siswa kelas IV SD Negeri Sekecamatan Kutowinangun.

Secara deskriptif, rata-rata kemampuan berpikir kritis siswa kelas Problem Based Learning pada saat pretest sebesar 44.48 dan posttest sebesar 72.56, selisihnya adalah 28,08. Rata-rata kemampuan berpikir kritis siswa kelas Ekspositori pada saat pretest sebesar 41.91 dan posttest sebesar 60.16 , selisinnya yaitu 18,25. Berdasarkan data tersebut, diketahui bahwa setelah pelaksanaan pembelajaran terdapat peningkatan kemampuan berpikir kritis siswa, terlihat pada hasil posttest yang 
meningkat, baik pada pembelajaran dengan model Problem Based Learning maupun ekspositori.

Penerapan model pembelajaran Problem Based Learning dapat meningkatkan kemampuan berpikir kritis. Menurut Kusumawati dan Adawiyah (2019: 36) dalam pembelajaran Problem Based Learning terdapat kegiatan pemecahan masalah yang menjadikan siswa untuk lebih memahami isi pelajaran, menantang kemampuan siswa serta memberikan kepuasan untuk menemukan pengetahuan baru siswa, menjadikan siswa lebih aktif dalam pembelajaran, membantu siswa untuk memahami masalah yang nyata berdasarkan pengetahuan yang dimiliki, dan memperlihatkan kepada siswa bahwa mata pelajaran pada dasarnya merupakan kegiatan berpikir. Strobel \& Van Barneveld (Ulger: 2018) juga berpendapat bahwa "Problem Based Learning is an ideal learning approach that teachers can use to help students determine solutions to nonroutine problems." Yang artinya bahwa pembelajaran berbasis masalah adalah pendekatan pembelajaran yang ideal yang dapat digunakan guru untuk membantu siswa menentukan solusi untuk masalah non-rutin. Keunggulan tersebut dapat menjadikan siswa untuk mampu menghubungkan antara konsep dengan permasalahan yang ada dalam kehidupan dan melatih siswa untuk bertanggung jawab serta mempertajam keahlian berpikir tingkat tinggi melalui kegiatan identifikasi masalah, analisis masalah, dan menciptakan solusi.

Hasil analisis dalam penelitian ini sesuai dengan teori yang ada bahwa model Problem Based Learning dapat meningkatkan kemampuan berpikir kritis. Sesuai pendapat Smith (Amir, 2010: 27) yang menyatakan bahwa model Problem Based Learning dapat meningkatkan kecakapan pemecahan masalah, lebih mudah mengingat, meningkatakan pemahaman dan pengetahuan yang relevan dengan dunia praktik serta mendorong siswa untuk penuh pemikiran. Setyorini (Hasan \& Syatriandi, 2018: 139) berpendapat bahwa model Problem Based Learning dapat meningkatkan kemampuan berpikir kritis karena setiap langkah dalam pembelajaran memiliki tujuan agar siswa aktif menumbuhkan kemampuan berpikir kritis. Pembelajaran dengan model Problem Based Learning dapat meningkatkan kemampuan berpikir kritis pada siswa. Hal ini didukung oleh penelitian yang dilakukan Sholicha \& Wulandari (2020) yang menyatakan bahwa model Problem Based Learning memiliki pengaruh signifikan terhadap peningkatan kemampuan berpikir kritis kelas $\mathrm{X}$ yang dibuktikan dengan hasil uji-t memperlihatkan signifikasi sebesar 0,000.

Menurut Marisa (2019) model pembelajaran ekspositori memiliki empat langkah pembelajaran yaitu a) persiapan, yaitu tahap mempersiapkan siswa untuk menerima pelajaran; b) penyajian, yaitu tahap penyampaian materi oleh guru; c) korelasi, yaitu tahap mengaitkan materi pembelajaran kehidupan siswa; dan d) menyimpulkan, yaitu tahap memahami inti dari pelajaran. Dalam langkah pembelajaran ekspositori tersebut terdapat langkah mengaitkan pembelajaran dengan kehidupan siswa, hal ini akan mengembangkan kemampuan berpikir kritis siswa. Siswa akan mampu menerapkan pengetahuan dengan kehidupan nyata siswa serta mampu memecahkan permasalahan yang ada dalam kehidupan siswa. Hal ini memperkuat hasil penelitian bahwa model ekspositori dapat meningkatkan kemampuan berpikir kritis siswa.

\section{SIMPULAN}

Berdasarkan penelitian, dapat disimpulkan bahwa terdapat pengaruh model Problem Based Learning dan ekspositori terhadap kemampuan berpikir kritis dalam pembelajaran IPS tentang keragaman budaya kelas IV SD negeri se-Kecamatan Kutowinangun yang ditunjukkan pada uji hipotesis bahwa nilai Sig. sebesar 0,000 < 0.05 . Implikasi teoretis penelitian ini yaitu penemuan ini memperkuat penelitian dan teori sebelumnya tentang pengaruh model pembelajaran Problem Based Learning dan ekspositori terhadap kemampuan berpikir kritis siswa dalam pembelajaran IPS dan 
memberikan sumbangan pengetahuan bahwa penerapan model Problem Based Learning dapat meningkatkan kemampuan berpikir kritis siswa. Implikasi praktis penelitian ini yaitu penerapan model yang lebih menuntut siswa untuk aktif belajar seperti model Problem Based Learning, akan meningkatkan kemampuan berpikir kritis siswa.

Berdasarkan simpulan dan implikasi yang telah disebutkan, peneliti memberikan saran sebagai berikut: 1) bagi guru dalam penggunaan model pembelajaran Problem Based Learning dan ekspositori guru perlu mempertimbangkan kesesuaian antara materi pembelajaran dengan model pembelajaran yang akan digunakan, 2) bagi siswa, siswa harus lebih aktif belajar dan berpikir dalam kegiatan pembelajaran IPS maupun materi lain, 3) bagi sekolah, sekolah dapat mempertimbangan untuk menggunakan model pembelajaran ini, terutama model Problem Based Learning untuk meningkatkan kemampuan berpikir kritis siswa.

\section{DAFTAR PUSTAKA}

Amin, S. (2017). Pengaruh model pembelajaran Problem Based Learning terhadap kemampuan berpikir kritis dan hasil belajar geografi. JurnalPendidikan Geografi, 4 (3). Diperoleh pada 28 Desember 2019 dari https:/ppjp.ulm.ac.id/journal/index.php/jpg/article.

Amir, T. (2010). Inovasi pendidikan melalui Problem Based Learning. Jakarta: Prenada Media Group.

Anggriani, F., Karyadi, B., \& Ruyani. (2018). Kemampuan berpikir kritis siswa melalui pembelajaran berbasis lingkungan untuk studi ekosistem sungai. Journal of Science Education, 2(3), 100-105. Diperoleh pada 3 Januari 2020dari https://ejournal.unib.ac.id/index.php/pendipa/article/view/7701.

Fisher, A. (2017). Berpikir kritis: Sebuah pengantar. Jakarta: Penerbit Erlangga.

Harjono, A., Gunada, L., Sutrio., \& Hikmawati. (2018). Penerapan advance organizer dengan model pembelajaran ekspositori berpola lesson study untuk meningkatkan hasil belajar fisika peserta didik . Jurnal Pendidikan Fisika dan Teknologi, 4(1). Diperoleh pada 6 Januari 2020 dari http://jurnalfkip.unram.ac.id/index.php/JPFT/article/view/736.

Sianturi, A., Sipayung, T., \& Simorangkir, F. Pengaruh Model Problem Based Learning (PBL) Terhadap Kemampuan Berpikir Kritis Matematis Siswa SMPN 5 Sumbul. Jurnal Pendidikan Matematika 6 (1). Diperoleh pada 16 Juni 2020 dari https://jurnal.ustjogja.ac.id/index.php/union/article/view/2082.

Solicha, D \& Wulandari, S. Pengaruh Model Pembelajaran Problem Based Learning Terhadap Kemampuan Berpikir Kritis dan Hasil Belajar Siswa Kelas X OTKP di SMK Negeri 2 Tuban. Jurnal Pendidikan Administrasi Perkantoran 8 (1). Diperoleh pada $16 \quad 2020$ Juni https://journal.unesa.ac.id/index.php/jpap/article/view/8087.

Ulger, K. (2018). The effect of problem-based learning on the creative thinking and critical thinking disposition of students in visual arts education. Interdisciplinary Journal of Problem-Based Learning, 12(1). Diperoleh pada 5 Januari 2020 dari https://docs.lib.purdue.edu/ijpbl/vol12/iss1/10/.

Wulandari., Astuti., dan Widodo. (2018). Efektivitas model pembelajaranProblemBased Learning terhadap hasil belajar ipa ditinjau dari 
kemampuan berkomunikasi siswa. Jurnal Pijar MIPA, 13(1). Diperoleh pada 29 Desember $2019 \quad$ darl http://jurnalfkip.unram.ac.id/index.php/JPM/article/view/538 